\title{
Recorder Device
}

National Cancer Institute

\section{Source}

National Cancer Institute. Recorder Device. NCI Thesaurus. Code C50134.

A device designed to capture and store audiovisual or other data. 